\title{
Assessment of Radiation Dose Rates in the High Terrestrial Gamma Radiation Area of Selama District, Perak, Malaysia
}

\author{
Ahmad Termizi Ramli \\ Department of Physics, Faculty of Science \\ Universiti Teknologi Malaysia, Johor 81310, Malaysia \\ Tel: 60-1-9725-8470 E-mail:a_hma_d2003@yahoo.co.uk \\ Nursama Heru Apriantoro (Corresponding author) \\ Department of Physics, Faculty of Science \\ Universiti Teknologi Malaysia, Johor 81310, Malaysia \\ Tel: 60-1-6704-5707 E-mail: nursama_91@yahoo.co.id \\ Husin Wagiran \\ Department of Physics, Faculty of Science \\ Universiti Teknologi Malaysia, Johor 81310, Malaysia
}

This project is funded by The Atomic Energy Licensing Board of Malaysia (Vot no. 68876). This project also used various facilities provided by Universiti Teknologi Malaysia and the Malaysian Nuclear Agency.

\begin{abstract}
Survey of terrestrial gamma radiation (TGR) dose rates have been conducted in Selama district, Perak, Malaysia. The mean value of TGR dose rate outdoor in Selama is $(273 \pm 133) \mathrm{nGy} \mathrm{h}^{-1}$. For the habited land, the mean TGR dose rates outdoor and indoor are $(205 \pm 59) \mathrm{nGy} \mathrm{h}^{-1}$ and $(212 \pm 64) \mathrm{nGy} \mathrm{h}^{-1}$ respectively. They contribute fatal cancer risk of $6.4 \mathrm{x}$ $10^{-5}$ per year to an individual in the area. The activity concentrations of ${ }^{238} \mathrm{U},{ }^{232} \mathrm{Th}$, and ${ }^{40} \mathrm{~K}$ in the soil samples were analysed using a high resolution co-axial HPGe gamma ray spectrometer system. The values obtained range from $57 \mathrm{~Bq}$ $\mathrm{kg}^{-1}$ to $364 \mathrm{~Bq} \mathrm{~kg}^{-1}$ with the mean value of $(178 \pm 95) \mathrm{Bq} \mathrm{kg}^{-1}$ for ${ }^{238} \mathrm{U} ; 207 \mathrm{~Bq} \mathrm{~kg}^{-1}$ to $625 \mathrm{~Bq} \mathrm{~kg}^{-1}$ with the mean value of $(353 \pm 143) \mathrm{Bq} \mathrm{kg}^{-1}$ for ${ }^{232} \mathrm{Th}$, and $26 \mathrm{~Bq} \mathrm{~kg}^{-1}$ to $601 \mathrm{~Bq} \mathrm{~kg}^{-1}$ with the mean values of $(273 \pm 133) \mathrm{Bq} \mathrm{kg}^{-1}$ for ${ }^{40} \mathrm{~K}$.
\end{abstract}

Keywords: TGR dose rate, ${ }^{238} \mathrm{U},{ }^{232} \mathrm{Th},{ }^{40} \mathrm{~K}$, radiation risk

\section{Introduction}

Naturally occurring radioactive materials (NORM) existing in soil could pose potential health physics risk (Wilson, 1993), especially if assisted by natural processes such as weathering deposition and wind erosion (Elles et al., 1997). The radiological impact of NORM to the human populations is due to terrestrial gamma radiation, inhalation of air contaminated with radon gas and other radionuclide particulate, consumption of the agricultural products, water and their products (Kryshev et al., 1996). The terrestrial gamma radiation dose rate is influenced by soil types, geological features and geographical condition (Florou \& Kritidis., 1992; Ramli, 1997). Human beings are exposed outdoors to the natural terrestrial radiation that originates predominantly from the upper $30 \mathrm{~cm}$ of the soil (Narayana et al., 1994). The high terrestrial gamma radiation dose rates are mostly found in areas with soils originating from granitic rocks (Kogan et al., 1969). The concentration of uranium and thorium in the soil in the area is also high. The world average values for terrestrial gamma radiation dose rates outdoor for the world and Malaysia are $57 \mathrm{nGy} \mathrm{h}^{-1}$ and $75 \mathrm{nGy} \mathrm{h}^{-1}$ respectively (UNSCEAR, 2000). The highest concentrations of radioactive minerals in soil are found in Brazil (Radhakrishna et al., 1993). 
Selama has an area of $746 \mathrm{~km}^{2}$ and population of about 36405 (Selama District Council, 2009). It is one of 10 districts of Perak state. Its capital is also called Selama. It is located between the latitudes $5^{\circ} 05^{\prime}$ to $5^{\circ} 26^{\prime}$ North, and the longitudes $100^{\circ} 37^{\prime}$ to $100^{\circ} 57^{\prime}$ East. It is bordered on the north by Kedah State, on the east by Hulu Perak district, on the south by Larut Matang district and to the west by Kerian district. $66 \%$ of the district is covered by forest (hills, mountains) and the main land use is for agriculture. The climate is tropical with temperature between $28^{\circ} \mathrm{C}$ to $32^{\circ} \mathrm{C}$. Selama can be divided into four major geological groups of different geological ages (Director General of Geological Survey, 1985) as shown in Figure 1, that are Quaternary (mainly recent alluvium), Triassic-Jurassic (sediments rocks with conglomerates), Silurian (sediments rocks with associated lava and tuff), and acid and undifferentiated (granitic rocks). Granite based geological features is most abundant in Selama, it cover about $75 \%$ of the area, and followed by Silurian (12\%), Triassic (9\%), and Quaternary (4\%). Selama is overlaid by five types of soil as classified by FAO /UNESCO (Director General of Agriculture Peninsular Malaysia, 1973). The soil types present according to FAO/UNESCO classification are Haplic Acrisol (locally are refered as Holyrood, Harimau), Dystric Fluvisol-Haplic Arenosol-Dystric Cabisol (Aluvium Tempatan- Telemong-Akob), Haplic Acrisol-Ferric Acrisol (Rengam-Bukit Temiang), Haplic Acrisol-Haplic Ferralsol (Serdang-Munchong) and steep land (miscellaneous soils). Soil types in Selama are shown in Figure 2.

The results obtained for this area can be used to determine the natural radiological background and can be used as one of the baseline data in the assessments of the environmental impacts of amang deposits and nuclear accidents.

\section{Materials and Methods}

\subsection{Terrestrial gamma radiation (TGR) dose rates}

The terrestrial gamma radiation dose rate was measured 1 meter above the ground by using two identical gamma-ray detectors and the average value was recorded. The detector used was model 19, micro roentgen ( $\mu \mathrm{R}$ ) meter, manufactured by Ludlum, USA. It uses $1^{\prime \prime} \times 1 "\left(2.54 \times 2.54 \mathrm{~cm}^{2}\right)$ sodium iodide $(\mathrm{NaI})$ crystal doped with thallium $(\mathrm{Tl})$. The instrument was calibrated by Malaysia Nuclear Agency, it is a Secondary Standard Dosimetry Laboratory (SSDL). The terrestrial gamma radiation (TGR) dose rates were measured from locations with different soil types and geological backgrounds randomly, the results of TGR dose rate measurements are presented as an isodose contour map. The isodose map was drawn by using software surfer and modified according to soil type, geological background, and topological information. It is shown in Figure 3.

\subsection{Concentration of ${ }^{238} U,{ }^{232}$ Th and ${ }^{40} \mathrm{~K}$ in soil samples}

Soil samples were collected from locations with different terrestrial gamma radiation dose rates, soil types and geological features. All samples were dried by placing them in an oven at $110^{\circ} \mathrm{C}$ for 24 hours then crushed and ground to fine powder by using a grinding mill (Herzog-D4500/type HSM 100, No. 62B/529, German-made). The samples were sieved by passing through a $200 \mathrm{~mm}$ test sieve/150 microns to be homogenized in size. Samples were sealed in plastic containers and left for at least one month, before gamma spectrometric analysis, to ensure secular equilibrium (Mollah et al.,1987; Ibrahim et al., 1993). The specific activity in soil (in $\mathrm{Bq} \mathrm{kg}^{-1}$ ) due to radionuclide $i$ and for a peak at energy $E$, is given by Equation (1) (IAEA 1989),

$$
A_{E i}=\frac{N_{E i}}{\varepsilon_{E i} t \gamma_{E i} M}
$$

where $N_{E i}$ is the net peak area at energy $E_{i}$ of radionuclide i, $\varepsilon_{E \mathrm{i}}$ is the detection efficiency at energy $E, t$ is the counting time, $\gamma_{E i}$ is the number of gammas per nuclear transformation of the radionuclide at energy $E$, and $M$ is the mass in $\mathrm{kg}$ of the measured sample. The minimum detectable activity for counting time $10,800 \mathrm{~s}$ were estimated to be $4 \mathrm{~Bq} \mathrm{~kg}^{-1}, 9 \mathrm{~Bq}$ $\mathrm{kg}^{-1}$ and $19 \mathrm{~Bq} \mathrm{~kg}{ }^{-1}$ for ${ }^{238} \mathrm{U},{ }^{232} \mathrm{Th}$ and ${ }^{40} \mathrm{~K}$ respectively.

Gamma ray spectrometric analysis of radionuclides were carried out by using a coaxial high purity germanium (HPGe) detector. The concentration of the radionuclide considered was determined from the peaks at $239 \mathrm{keV}\left({ }^{212} \mathrm{~Pb}\right), 583 \mathrm{keV}$ $\left({ }^{208} \mathrm{Tl}\right)$ and $911 \mathrm{keV}\left({ }^{228} \mathrm{Ac}\right)$ for ${ }^{232} \mathrm{Th}$, the peaks at $352 \mathrm{keV}\left({ }^{214} \mathrm{~Pb}\right)$ and $609 \mathrm{keV}\left({ }^{214} \mathrm{Bi}\right)$ for the ${ }^{238} \mathrm{U}$ and the peak at 1 $460 \mathrm{keV}$ for ${ }^{40} \mathrm{~K}$. The standard samples IAEA SL-14 and IAEA SL- 2 were used as reference materials and were mixed with $\mathrm{SiO}_{2}$ in Marinelli beakers. For calibration, the IAEA reference materials ${ }^{133} \mathrm{Ba},{ }^{22} \mathrm{Na},{ }^{137} \mathrm{Cs}$, ${ }^{60} \mathrm{Co}$ and ${ }^{152} \mathrm{Eu}$, were used. To determine the detection efficiency of gamma energies from $200 \mathrm{keV}$ to $2000 \mathrm{keV}$, Equation (2) was used,

$$
\operatorname{Ln} \varepsilon=1.09-0.79 \operatorname{Ln} E
$$

where $\varepsilon$ is the detection efficiency and $E$ is the gamma ray energy in $\mathrm{keV}$. The minimum detectable activity for counting time of $10800 \mathrm{~s}$ were estimated to be $4 \mathrm{~Bq} \mathrm{~kg}^{-1}, 9 \mathrm{~Bq} \mathrm{~kg}^{-1}$ and $19 \mathrm{~Bq} \mathrm{~kg}^{-1}$ for ${ }^{238} \mathrm{U},{ }^{232} \mathrm{Th}^{2}$ and ${ }^{40} \mathrm{~K}_{\text {respectively. }}$

\section{Results and discussion}

The mean value of terrestrial gamma radiation dose rates in Selama and other areas in Malaysia and the world are 
presented in Table 1. The value of terrestrial gamma radiation dose rates measured from the 140 outdoor locations, ranged from $64 \mathrm{nGy} \mathrm{h}^{-1}$ to $715 \mathrm{nGy} \mathrm{h}^{-1}$, with the mean value of $(273 \pm 133) \mathrm{nGy} \mathrm{h} \mathrm{h}^{-1}$. This value is higher than the world and the Malaysian average as reported by UNSCEAR 2000. The mean TGR dose rate value in this area is higher than other areas of Perak, except for the area of Kg. Sg. Durian (Ramli et al., 2009, in communication). For the habited land in Selama, the mean TGR outdoor dose rate value is $(205 \pm 59) \mathrm{nGy} \mathrm{h}^{-1}$. For the forested areas, the mean TGR dose rate outdoor is $(351 \pm 152) \mathrm{nGy} \mathrm{h}^{-1}$.

TGR dose rates indoor for concrete houses in the high TGR dose rate areas were calculated using Equation (3) (Ramli, et al, 2009, in communication).

$$
D_{\text {in }}=0.33 D_{\text {out }}+144
$$

where $D_{\text {in }}$ and $D_{\text {out }}$ are TGR dose rate indoor and outdoor respectively. The indoor mean value for Selama district is estimated to be $(212 \pm 64) n G y h^{-1}$ for concrete houses.

The mean values of terrestrial gamma radiation dose rates for the five soil types and four geological backgrounds found in Selama are presented in Table 2. The steep lands and Haplic Acrisol-Ferric Acrisol (Rengam, Bukit Temiang) appear to have the higher mean TGR dose rates values. The steep lands mean value is $(379 \pm 143) \mathrm{nGy} \mathrm{h}^{-1}$ with values ranging from $234 \mathrm{nGy} \mathrm{h}^{-1}$ to $696 \mathrm{nGy} \mathrm{h}^{-1}$, and the Haplic Acrisol-Ferric Acrisol mean value is $(306 \pm 161) \mathrm{nGy} \mathrm{h}^{-1}$ with values ranging from $64 \mathrm{nGy} \mathrm{h}^{-1}$ to $715 \mathrm{nGy} \mathrm{h}^{-1}$. These soils were formed with granite as parent material. The highest mean TGR dose rate value based on geological background was found in acid undifferentiated areas. The mean value is (337 $\pm 16) \mathrm{nGy} \mathrm{h}{ }^{-1}$ and ranged from $165 \mathrm{nGy} \mathrm{h}^{-1}$ to $715 \mathrm{nGy} \mathrm{h}^{-1}$. The area are igneous acidic and extensively intruded by granitic rocks. The granite is relatively rich in radioactive minerals (UNSCEAR, 2000).

The mean values of ${ }^{238} \mathrm{U},{ }^{232} \mathrm{Th}$ and ${ }^{40} \mathrm{~K}$ activity concentration in different soil samples are presented in Table 3 . The activity concentration of the 15 soil samples for ${ }^{238} \mathrm{U}$ ranged from $57 \mathrm{~Bq} \mathrm{~kg}^{-1}$ to $364 \mathrm{~Bq} \mathrm{~kg}^{-1}$, the mean value is $(178 \pm$ 95) $\mathrm{Bq} \mathrm{kg}{ }^{-1} ; 207 \mathrm{~Bq} \mathrm{~kg}^{-1}$ to $625 \mathrm{~Bq} \mathrm{~kg}^{-1}$ for ${ }^{232} \mathrm{Th}$, the mean value is $(353 \pm 143) \mathrm{Bq} \mathrm{kg}^{-1}$; and $36 \mathrm{~Bq} \mathrm{~kg}^{-1}$ to $601 \mathrm{~Bq} \mathrm{~kg}^{-1}$ for ${ }^{40} \mathrm{~K}$, the mean value is $(296 \pm 184) \mathrm{Bq} \mathrm{kg}^{-1}$. The average activity concentrations of ${ }^{238} \mathrm{U}$ and ${ }^{232} \mathrm{Th}$ in the soils of these areas are higher than the world average as reported in UNSCEAR 2000, but the activity concentration for ${ }^{40} \mathrm{~K}$ is lower than world average value of $400 \mathrm{~Bq} \mathrm{~kg}^{-1}$. The most abundant primordial radionuclide is thorium $\left({ }^{232} \mathrm{Th}\right)$. It is about $43 \%$ of the total $\left({ }^{232} \mathrm{U}+{ }^{232} \mathrm{Th}+{ }^{40} \mathrm{~K}\right) .{ }^{238} \mathrm{U}$ is $21 \%$ and ${ }^{40} \mathrm{~K}$ is $36 \%$. The correlation between gamma dose rate in situ with the activity concentration of ${ }^{232} \mathrm{U},{ }^{232} \mathrm{Th}$ and ${ }^{40} \mathrm{~K}$ in soil samples are given in Figure. 4.

Using the conversion coefficient factor for the absorbed dose in air to effective dose of $0.7 \mathrm{~Sv} \mathrm{~Gy}^{-1}$, as recommended by UNSCEAR 2000 and the outdoor occupancy factor of 26\% (Ramli et al., 2009, in communication), the annual effective dose $\left(H_{E}\right)$ is calculated by using Equation (4),

$$
H_{E}\left(\mathrm{mSv} \mathrm{y}^{-1}\right)=\text { Dose rate }\left(\mathrm{nGy} \mathrm{h}^{-1}\right) \text { x } 24 \text { hours } \mathrm{x} 365 \text { days } \mathrm{x} O F \mathrm{x} 0.7 \mathrm{x} 10-6
$$

where $H_{E}$ is annual effective dose in $\mathrm{mSv}$, and $O F$ is occupancy factor that is 0.74 and 0.26 for indoor and outdoor respectively.

The average annual effective dose equivalent received in habited areas of Selama District are $0.96 \mathrm{mSv}$ and $0.33 \mathrm{mSv}$ for indoor (concrete houses) and outdoor respectively. The world annual effective dose equivalent average value are $0.41 \mathrm{mSv}$ indoor and $0.07 \mathrm{mSv}$ outdoor (UNSCEAR, 2000). The annual effective dose rate outdoor will be higher for steep lands, and areas with acid undifferentiated geological background; its mean value is $1.17 \mathrm{mSv}$. But these areas are not populated being mostly pristine jungle.

To estimate the fatal cancer risk to an individual $\hat{R}_{i}$, Equation (5) is used (Alvarez, 1997):

$$
\hat{R}_{i}=a \sum H_{E} \text {, or } \hat{R}_{i}=a\left(H_{E_{\text {in }}}+H_{\text {Eout }}\right)
$$

where $a$ is the risk factor, that is 0.05 death per sievert (ICRP 1990). $H_{E i n}$ and $H_{E o u t}$ are effective dose rates indoor and outdoor respectively. The value of fatal cancer risk is about 6.4. $\times 10^{-5}$ per year to each individual living in habited land of Selama.

\section{Conclusion}

The mean terrestrial gamma radiation dose rate in Selama is about 3 times higher than the Malaysian average and about 5 times higher than the world average value. Eventhough the mean TGR dose rate is relatively high but the higher dose rate areas are mostly in unhabited areas, therefore the annual effective dose rate is less than the expected value based on the mean value for the Selama district. Nevertheless the average total fatal cancer risk of $6.4 \times 10^{-5}$ per year to each individual in the Selama district is too small to cause alarm.

The higher values of terrestrial gamma radiation dose rate are associated with soils of granitic origin, which are Haplic Acrisol-Ferric Acrisol and steep land. These soils were formed with granite as parent material. The highest TGR dose 
rate values based on geological background are found in acid undifferentiated (acid intrusive) areas, they are granitic. Granite is relatively rich in radioactive minerals. The most abundant radionuclide in the study areas is thorium- 232 .

\section{References}

Abdul Rahman, A.T. \& Ramli, A.T. (2007). Radioactivity levels of ${ }^{238} \mathrm{U}$ and ${ }^{232} \mathrm{Th}$, the $\alpha$ and $\beta$ activities and associated dose rates from surface soil in Ulu Tiram, Malaysia. Journal of Radio analytical and Nuclear Chemistry, 273 (3), 653-657.

Alvarez, JL. (1997). Ionizing Radiation Risk Assessment, in: Molak, V (eds.), Fundamental of Risk Analysis and Risk Management. CRC Press. pp. 163-175.

Director General of Geological Survey. (1985). Map of Geological Features in Peninsular Malaysia. Ipoh.

Director General of Agriculture Peninsular Malaysia. (1973). Map of Soil Types in Peninsular Malaysia. $1^{\text {st }}$ Edition. Kuala Lumpur.

Elless, MP., Armstrong, AQ. \& Lee, SY. (1997). Characterization and solubility measurements of uranium-contaminated soils to support risk assessment. Journal of Health Phyics, 72, 716-726.

Florou, H., \& Kritidis, P. (1992). Gamma radiation measurements and dose rate in the coastal areas of a volcanic island, Aegean Sea, Greece. Journal of Radiation Protection Dosimetry, 45, 277-279.

Ibrahim, N.M., Abd El Ghani, A.H., Shawky, E.M., Ashraf, E.M., \& Farouk, M.A. (1993). Measurement of radioactivity levels in soils in the Nile Delta and Middle Egypt. Journal of Health Physics, 64, 620-627.

ICRP. (1990). Recommendations of the International Commission on Radiological Commission. ICRP Publication 60. Pergamon Press: New York.

Kogan, R.M., Nazarov, I.M., \& Fridman, S.D. (1969). Gamma Spectrometry of Natural Environments and Formation : Theory of The Method Application to Geology dan Geophysics. Keter Press: Jerusalem.

Kryshev, I.I., Sazykina, T.G., \& Isaeva, L.N. (1996). Risk assessment from contamination of aquatic ecosystem in the areas of Chernobyl. Journal of Radiation Protection Dosimetry, 64, 103-107.

Lee, S.K., Wagiran, H., Ramli., A.T., Apriantoro, N.H., \& Wood., A.K. (2009). Radiological monitoring : terrestrial natural radionuclides in Kinta District, Perak, Malaysia. Journal of Environmental Radioactivity, 100, 368-374.

Mollah, S., Rahman, N.M., Kodlus, M.A., \& Husain, S.R. (1987). Measurement of high natural background radiation level by TLD at Cox and Bazar coastal areas in Bangladesh. Journal of Radiation Protection Dosimetry, 18, 39 - 41.

Narayana, Y., Somashekarappa, H.M., Radhakrishna, A.P., Balakrishna, K.M., \& Siddappa,K. (1994). External gamma radiation dose rate in coastal Karnataka. Journal of Radiology Protection. 14, 257-264.

Radhakrishna, A.P., Somashekarappa, H.M., Narayana, Y., \& Siddappa, K. (1993). A new natural background radiation area on the southwest coast of India. Journal of Health Physics, 65, 390 - 395.

Ramli, A,T. (1997). Environmental Terrestrial Gamma Radiation Dose and its Relationship with Soil Type and Underlying Geological Formation in Pontian District, Malaysia. Journal of Applied Radiation and Isotopes, 48, 407-412.

Ramli, A,T., Apriantoro, N,H., Wagiran, H., Lee, S.K., \& Wood, A.K. (2009). Health Risk implications of high background radiation dose rate in Kampung Sungai Durian, Kinta District, Perak, Malaysia. Global Journal of Health Science 1 (2), 140 - 149

Ramli, A.T., Abdel Wahab, M. A., \& Lee, M.H. (2001). Geological influence on terrestrial gamma radiation dose rate in the Malaysian State of Johore. Journal Applied Radiation and Isotopes, 54 (2), 327-333.

Ramli, A.T., Abdul Rahmana, A.T., \& Lee, M.H. (2003). Statistical prediction of terrestrial gamma radiation dose rate based on geological features and soil types in Kota Tinggi district, Malaysia. Journal of Applied Radiation and Isotopes, 59 (5-6), 393-405.

Ramli, A.T., Sahrone., S \& Wagiran, H. (2005). Terrestrial gamma radiation dose study to determine the baseline for environmental radiological health practices in Melaka state, Malaysia. Journal of Radiological Protection, 25, 435-450.

Selama District Council, (2009). Official website of Selama District Council. [Online] Available: http://www.mdselama.gov.my/homestay

UNSCEAR. (2000). Sources and effect of ionising radiation. United Nation Scientific Committee of the Effect Atomic Radiation Report on The General Assembly, United Nation; New York.

Willson, M.J. (1993). Anthropogenic and naturally occurring radioactive materials detected on radiological survey of properties in Monticello, Utah. Environmental Health Physics; $26^{\text {th }}$ midyear topical meeting, 24-28 January. pp. 564. 
Table 1. TGR dose rate in Selama compared with the other parts of Malaysia and the world.

\begin{tabular}{lccl}
\hline State/District in Malaysia & $\begin{array}{c}\text { Mean } \pm \mathrm{Sd} \\
\left(\mathrm{nGy} \mathrm{h}^{-1}\right)\end{array}$ & $\begin{array}{c}\text { Range } \\
\left(\mathrm{nGy} \mathrm{h}^{-1}\right)\end{array}$ & Reference \\
\hline Selama district, Perak & $273 \pm 133$ & $64-715$ & Present Study \\
Johor State & $163 \pm 122$ & $9-1262$ & Ramli et al., 2001 \\
Melaka State & $183 \pm 54$ & $54-378$ & Ramli et al., 2005 \\
Kinta district, Perak & $222 \pm 191$ & $39-1039$ & Lee et al., 2009 \\
Pontian district, Johor & 67 & $50-230$ & Ramli, 1997 \\
Kota Tinggi district, Johor & $180 \pm 20$ & $9-1262$ & Ramli et al., 2003 \\
Ulu Tiram, Johor & 200 & $98-409$ & Abdul Rahman, A.T. \& Ramli, 2007 \\
Kg Sungai durian, Perak & $458 \pm 295$ & $78-1039$ & Ramli et al., 2009 \\
Malaysia & 92 & $55-130$ & UNSCEAR, 2000 \\
World & 57 & $18-93$ & UNSCEAR, 2000 \\
\hline
\end{tabular}

Table 2. Terrestrial gamma radiation dose rate from different soil types and geological background in Selama, Perak

\begin{tabular}{|c|c|c|c|c|c|c|c|}
\hline \multirow{2}{*}{ Soil type and Geological background } & \multirow{2}{*}{$\begin{array}{c}\mathrm{N} \\
\text { sample }\end{array}$} & \multirow{2}{*}{$\begin{array}{c}\text { Mean } \\
\left(\text { nGy h}^{-1}\right)\end{array}$} & \multirow{2}{*}{ Std Dev } & \multicolumn{2}{|c|}{$\begin{array}{l}95 \% \text { Confidence } \\
\text { Interval for Mean }\end{array}$} & \multirow{2}{*}{ Min } & \multirow{2}{*}{ Max } \\
\hline & & & & Lower & Upper & & \\
\hline \multicolumn{8}{|l|}{ Soil types (FAO/UNESCO) } \\
\hline Haplic Acrisol-Haplic Acrisol & 23 & 241 & 63 & 213 & 268 & 129 & 357 \\
\hline \multicolumn{8}{|l|}{ Dystric fluvisol-Haplic Arenosol - } \\
\hline Dystric Cabisol & 30 & 220 & 46 & 203 & 237 & 123 & 311 \\
\hline Haplic Acrisol-Ferric Acrisol & 46 & 306 & 161 & 259 & 354 & 64 & 715 \\
\hline Haplic Acrisol-Haplic Ferralsol & 16 & 158 & 40 & 137 & 179 & 116 & 246 \\
\hline Steep land (Miscellaneous soils) & 25 & 379 & 143 & 320 & 438 & 234 & 696 \\
\hline \multicolumn{8}{|l|}{ Geological background } \\
\hline Acid and undifferentiated & 78 & 337 & 143 & 304 & 369 & 165 & 715 \\
\hline Quaternary & 12 & 155 & 38 & 131 & 179 & 121 & 233 \\
\hline Silurian & 36 & 222 & 44 & 207 & 237 & 116 & 278 \\
\hline Triassic-Jurassic & 14 & 152 & 59 & 118 & 186 & 64 & 311 \\
\hline Present study & 140 & 273 & 133 & 251 & 295 & 64 & 715 \\
\hline Malaysian average (UNSCEAR 2000) & & 92 & & & & & \\
\hline World average (UNSCEAR 2000) & & 57 & & & & & \\
\hline
\end{tabular}


Table 3. Concentration of ${ }^{238} \mathrm{U},{ }^{232} \mathrm{Th}$ and ${ }^{40} \mathrm{~K}$ in soil sample and the corresponding TGR dose rate in air $1 \mathrm{~m}$ above the ground

\begin{tabular}{|c|c|c|c|c|c|c|}
\hline \multirow{2}{*}{$\begin{array}{c}\text { Soil } \\
\text { sample }\end{array}$} & \multirow{2}{*}{ Soil Types (FAO/UNESCO) } & \multirow{2}{*}{ Geological Background } & \multicolumn{3}{|c|}{ Concentration $\left(\mathrm{Bq} \mathrm{kg}{ }^{-1}\right)$} & \multirow{2}{*}{$\begin{array}{l}\text { TGR dose rate } \\
\text { at The point } \\
\text { sampling }\end{array}$} \\
\hline & & & ${ }^{238} \mathrm{U}$ & ${ }^{232} \mathrm{Th}$ & ${ }^{40} \mathrm{~K}$ & \\
\hline S 1 & Haplic Acrisol-Haplic Acrisol & Quartenary & 126 & 252 & 290 & 260 \\
\hline $\mathrm{S}_{2}$ & Haplic Acrisol-Haplic Acrisol & Acid undifferentiated & 117 & 625 & 60 & 330 \\
\hline S 3 & $\begin{array}{l}\text { Dystric Fluvisol-Haplic Arenosol } \\
\text { - Dystric Cabisol }\end{array}$ & Silurian & 139 & 272 & 291 & 273 \\
\hline $\mathrm{S} 4$ & Haplic Acrisol-Ferric Acrisol & Triassic-Jurassic & 57 & 207 & 198 & 130 \\
\hline S 5 & Haplic Acrisol-Ferric Acrisol & Triassic-Jurassic & 65 & 384 & 215 & 142 \\
\hline S 6 & Haplic Acrisol-Ferric Acrisol & Acid undifferentiated & 158 & 459 & 378 & 390 \\
\hline S 7 & Haplic Acrisol-Ferric Acrisol & Acid undifferentiated & 152 & 245 & 251 & 260 \\
\hline S 8 & Haplic Acrisol-Ferric Acrisol & Acid undifferentiated & 140 & 211 & 464 & 234 \\
\hline S 9 & Haplic Acrisol-Ferric Acrisol & Acid undifferentiated & 206 & 507 & 104 & 429 \\
\hline $\mathrm{S} 10$ & Haplic Acrisol-Ferric Acrisol & Acid undifferentiated & 166 & 247 & 579 & 311 \\
\hline S 11 & Haplic Acrisol-Ferric Acrisol & Acid undifferentiated & 247 & 276 & 439 & 364 \\
\hline $\mathrm{S} 12$ & Haplic Acrisol-Ferric Acrisol & Acid undifferentiated & 364 & 521 & 36 & 520 \\
\hline $\mathrm{S} 13$ & Steep land & Acid undifferentiated & 286 & 566 & 78 & 559 \\
\hline S 14 & Haplic Acrisol-Haplic Ferralsol & Acid undifferentiated & 357 & 297 & 601 & 325 \\
\hline S 15 & $\begin{array}{l}\text { Dystric Fluvisol-Haplic Arenosol } \\
\text { - Dystric Cabisol }\end{array}$ & Silurian & 96 & 224 & 455 & 273 \\
\hline \multicolumn{2}{|c|}{ Present Study } & & $178 \pm 95$ & $353 \pm 143$ & $296 \pm 184$ & $273 \pm 133$ \\
\hline \multicolumn{2}{|c|}{ Malaysia average (UNSCEAR, 2000) } & & $66(49-86)$ & $82(63-110)$ & $310(170-430)$ & $92(55-130)$ \\
\hline \multicolumn{3}{|c|}{ World average (UNSCEAR, 2000) } & $35(16-110)$ & $30(11-64)$ & $400(140-850)$ & $57(18-93)$ \\
\hline
\end{tabular}

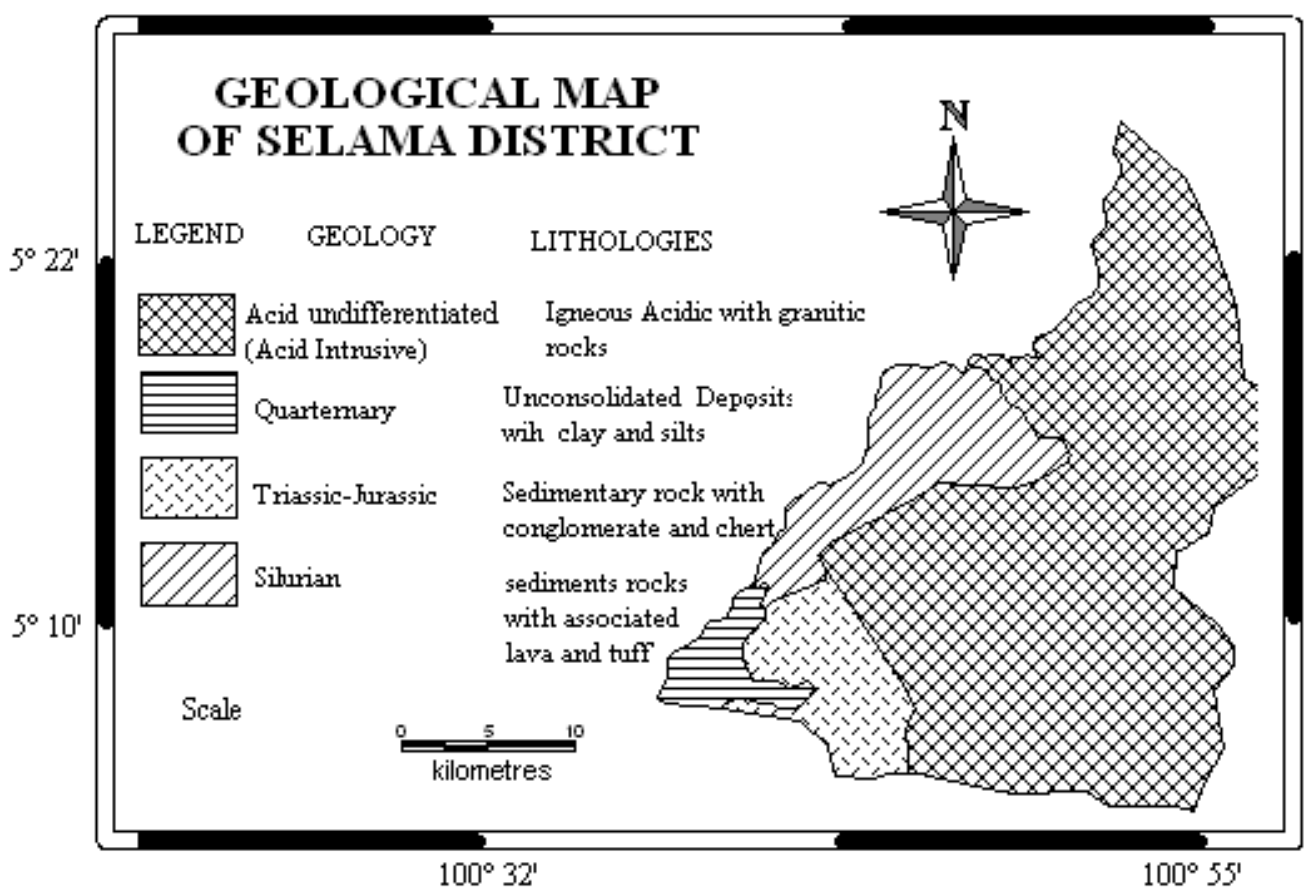

Figure 1. Map of geological features and its lithologies in Selama district, Perak, Malaysia (Director General of Geological Survey 1985) 


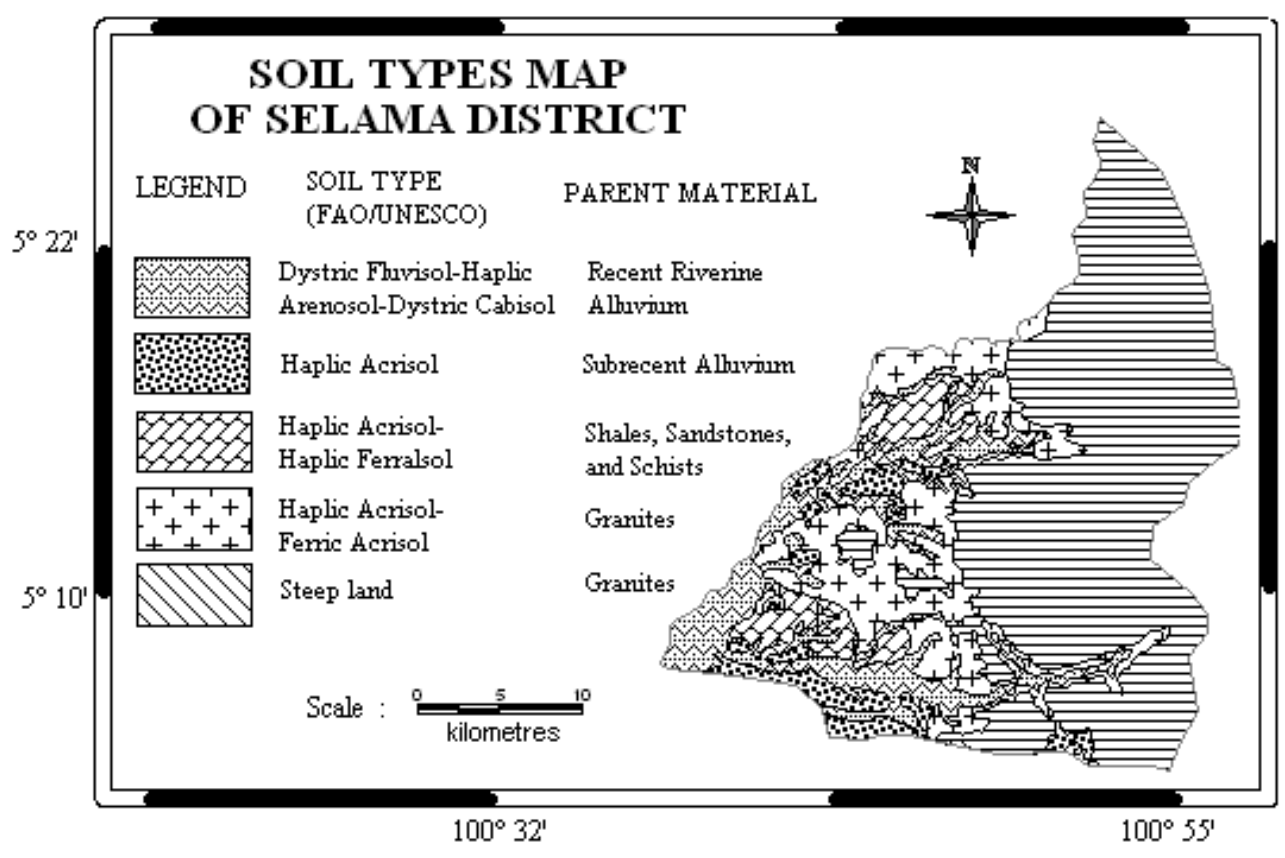

Figure 2. Map of soil types and its parent materials in Selama district, Perak, Malaysia (Directorate of National Mapping Malaysia, 1970).

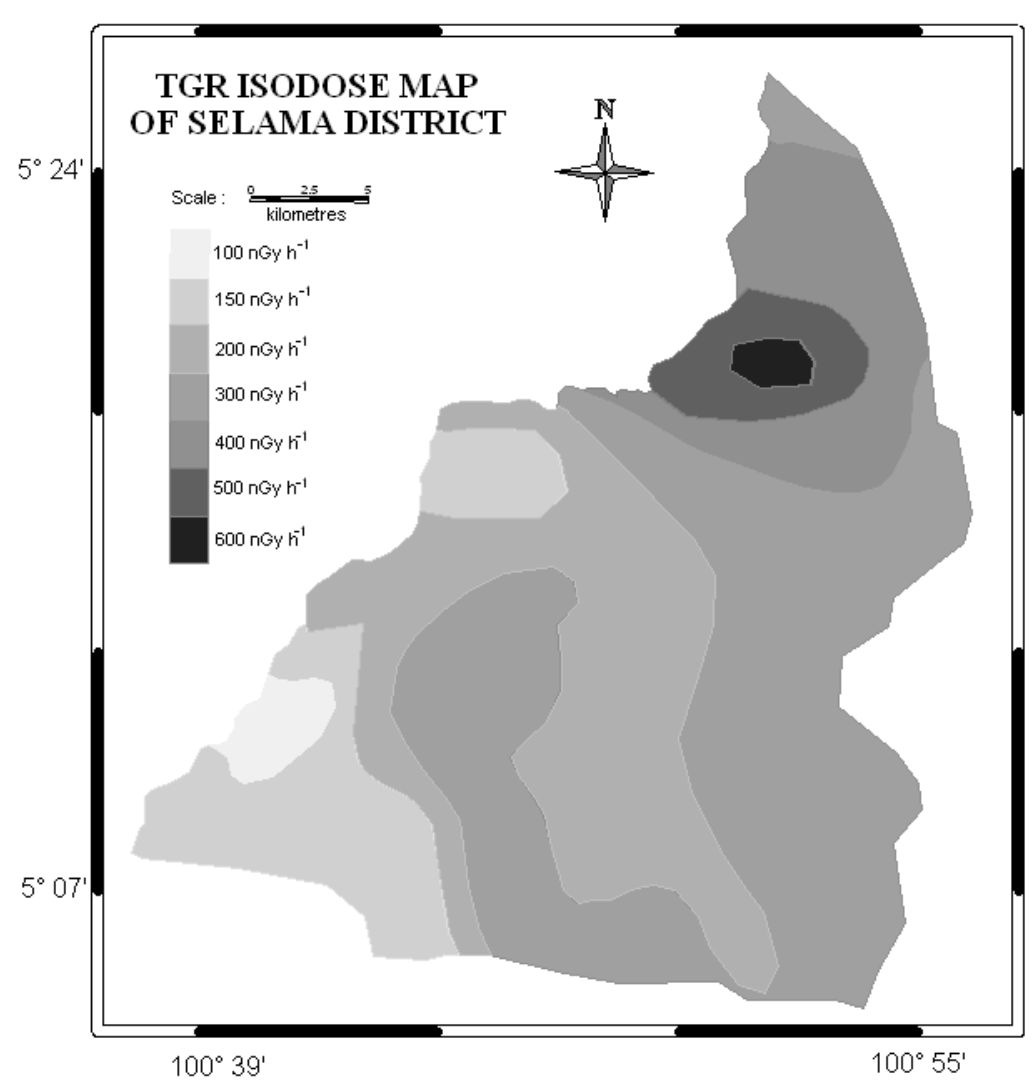

Figure 3. Map of terrestrial gamma radiation dose rates $\left(\mathrm{nGy} \mathrm{h}^{-1}\right)$ in Selama District, Perak, Malaysia 


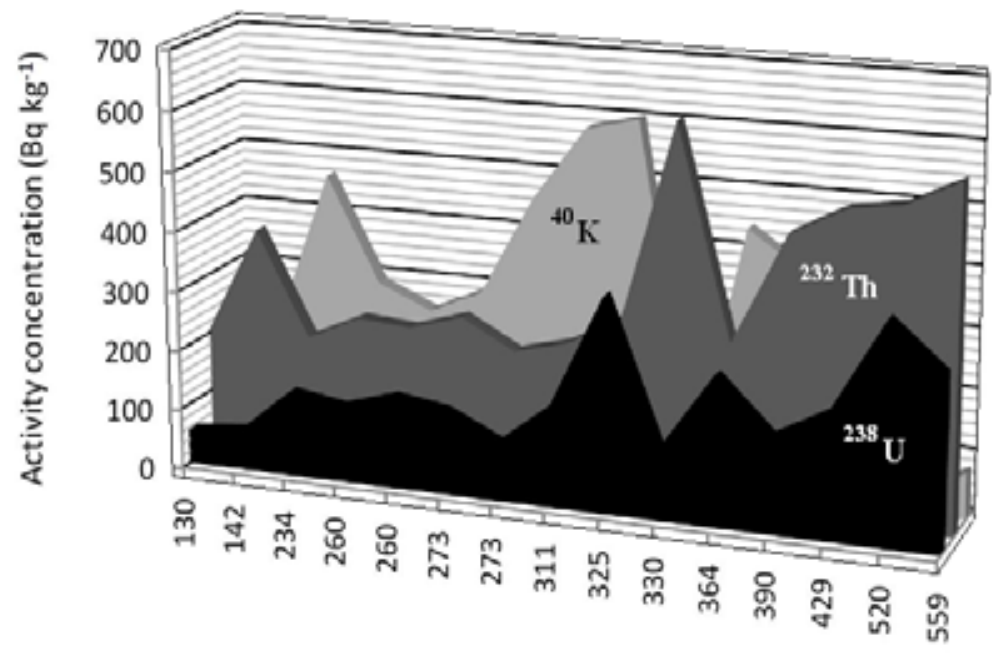

TGR dose rates (nGy h $h^{-1}$ )

Figure 4. The TGR dose rate versus activity concentration of ${ }^{238} \mathrm{U},{ }^{232} \mathrm{Th}$, and ${ }^{40} \mathrm{~K}$ in soil samples 